\title{
Butyrate stimulates Histone H3 acetylation, RANKL expression, but inhibited osteoprotegerin expression/secretion in MG-63 \\ Osteoblastic Cells
}

\section{Mei-Chi Chang ${ }^{1,2}$, Yunn-Jy Chen ${ }^{3, \#}$, Yun-Chia Lian'2, Bei-En Chang ${ }^{4}$, Chih-Chia Huang ${ }^{5}$, Wei-Ling Huang ${ }^{2}$, Yu-Hwa Pan ${ }^{2,6,}$, , Jiiang-Huei Jeng ${ }^{3, *}$}

${ }^{1}$ Chang Gung University of Science and Technology, Kwei-Shan, Taoyuan, Taiwan

2Department of Dentistry, Chang Gung Memorial Hospital, Taiwan

${ }^{3}$ School of Dentistry and Department of Dentistry, National Taiwan University Hospital and National Taiwan University Medical College, Taipei, Taiwan

${ }^{4}$ Graduate Institute of Oral Biology, National Taiwan University Medical College, Taiwan ${ }^{5}$ Department of Dentistry, Chang Gung Memorial Hospital, Taiwan

${ }^{6}$ Graduate Department of Craniofacial Dentistry, Chang-Gung University Medical College, Taoyuan, Taiwan

\#This author contributes equally to the first author.

\section{Address correspondence to:}

Prof. Jiiang-Huei Jeng

School of Dentistry and Department of Dentistry,

National Taiwan University Medical College and National Taiwan University Hospital

No 1, Chang Te Street,

Taipei

Taiwan

E-mail: jhjeng@ntu.edu.tw

\section{Or}

\section{Dr Yu-Hwa Pan}

Department of Dentistry,

Chang-Gung Memorial Hospital, Taipei Branch,

$6^{\text {th }}$ Floor, 199, Tung-Hwa North Road,

Taipei

Taiwan

E-mail: Shalom.dc@msa.hinet.net

Running title: Toxicity of butyrate on osteoblasts 


\section{Abstract}

Butyric acid as a histone deacetylase (HDAC) inhibitor was produced by a number of periodontal and root canal microorganisms (such as Porphyromonas, Fusobacterium etc.). Butyric acid may affect the biological activities of periodontal/periapical cells such as osteoblasts, periodontal ligament cells etc., and thus affect periodontal/periapical tissue destruction and healing. The purposes of this study were to study the toxic effects of butyrate on matrix and mineralization markers' expression of MG-63 osteoblasts. Cell viability and proliferation were determined by 3-(4,5-dimethylthiazol-2-yl) -2,5-diphenyl tetrazolium bromide (MTT) assay. Cellular apoptosis and necrosis were analyzed by propidium iodide/Annexin $\mathrm{V}$ flow cytometry. Protein and mRNA expression of OPG, and RANKL were analyzed by western blotting and RT-PCR. OPG, soluble RANKL (sRANKL), 8-isoprostane, pro-collagen I, MMP-2, osteonectin (SPARC), osteocalcin and osteopontin secretion into culture medium were measured by enzyme-linked immunosorbant assay. Histone $\mathrm{H} 3$ acetylation levels were evaluated by immunofluorescent staining (IF) and western blot. We found that butyrate induced morphologic changes of growing MG-63 cells, with bigger and flattened in appearance. Butyrate activated histone H3 acetylation of MG-63 cells. Exposure of MG-63 cells to butyrate partly decreased cell number with no marked increase in apoptosis and necrosis. Butyrate stimulated RANKL protein expression, whereas it inhibited OPG protein expression. Butyrate also inhibited the secretion of OPG in MG-63 cells, whereas SRANKL level was below detection limit. Butyrate stimulated 8-isoprostane, MMP-2 and osteopontin secretion, but not procollagen I, osteonectin, osteocalcin in MG-63 cells. In conclusion, butyric acid generated by periodontal and root canal microorganisms may potentially induce bony destruction and impair bone repair by alteration of OPG/RANKL expression/secretion, 8-isoprostane, MMP-2, and osteopontin secretion, and affect cell proliferation. These effects are possibly related to increased histone 
acetylation. These events are important in the pathogenesis of periodontal and periapical destruction.

Keywords: Bone resorption; Butyric acid; HDAC inhibitor; Osteoblasts; Osteoprotegerin/RANKL; Periodontal/root canal pathogens 


\section{Introduction}

Butyrate is a well-known histone deacetylase (HDAC) inhibitor [1]. Butyric acid can be generated by microorganisms present in the dental plaque and biofilms of the root surface and root canals, and involve in the pathogenesis of periodontitis and apical periodontitis. Periodontal and root canal (tooth pulp) pathogens, such as Porphyromonas gingivalis ( $P$. gingivalis) or other microorganisms, are widely distributed in the periodontal pocket, root canal and the apical area of the patients [2-7]. These pathogenic microorganisms are capable of attack, invading tissue cells or releasing toxic metabolites such as endotoxin, proteases, short chain fatty acids (e.g., propionic acid, butyric acid), which affect cellular responses [6-8].

Recent studies have found that butyrate plays an important role in periodontal and apical lesions in the gums and periodontal tissues. The concentrations of butyric acid may reach $0.2-16 \mathrm{mM}$ in gingival sulcus $[9,10]$ and the concentration of butyric acid in the root canals decreased after endodontic treatment [11]. Butyric acid may affect biological activities of periodontal/periapical cells such as osteoblasts, periodontal ligament cells, and gingival fibroblasts (GF) and inflammatory cells etc. [12-14], and thus affect periodontal/periapical tissue destruction and healing.

Bone homeostasis depends on the balance of bone resorption by osteoclasts and formation by osteoblasts. An imbalance of bone turnover may cause diseases such as osteoporosis, bone resorption, periodontitis etc. [15]. Interaction between osteoblasts and osteoclasts via direct contact or cytokine release is important for bone homeostasis. Osteoblasts may affect osteoclast activity through OPG/RANK/RANKL system [15]. An increase in RANK, RANKL and OPG expression in the progression of periodontitis and apical periodontitis has been reported [16-18]. An increase ratio of RANKL/OPG can be a marker showing the presence of periodontitis and bone resorption [18]. These changes in expression of OPG and RANKL during periodontitis may be related to the presence of various periodontal 
and root canal pathogens $[19,20]$ and related toxins. P. gingivalis LPS has been shown to affect RANKL and RANKL/OPG ratio of periodontal ligament fibroblasts [21]. However, limited information is known about butyric acid on OPG and RANKL expression of osteoblastic cells and its possible contribution in periodontal bony destruction.

Previously we have found that butyrate suppresses the adhesion, cell growth, protein synthesis, but induce reactive oxygen species and cell cycle arrest of gingival fibroblasts (GF) [22,12]. It also inhibited cell growth, collagen I expression, and induces cell cycle arrest, p21 and p27 expression of osteoblasts [23]. The purposes of this study were to further study the toxic effects (OPG, RANKL) of butyrate on MG-63 osteoblasts and the related mechanisms. Understanding these effects and mechanisms can help us with the treatment and prevention of subsequent periodontal and periapical diseases 


\section{Results}

\subsection{Stimulation of Histone H3 Acetylation by Butyrate}

Control MG63 cells showed limited nuclear staining of Ac-H3 (Figure 1A). Butyrate (8 mM) stimulated the histone $\mathrm{H} 3$ acetylation of MG-63 cells as analyzed by IF. An increase in red fluorescence of nuclear staining of MG-63 cells was noted after 120 min of exposure o $8 \mathrm{mM}$ butyrate (Figure 1A). An increase in Ac-H3 nuclear staining was also noted when MG-63 cells were exposed to butyrate for 24 hours (Figure 1B). Accordingly, butyrate stimulated Ac-H3 expression of MG-63 cells as analyzed by western blotting (Figure 1C).

\subsection{Morphology of MG-63 Cells after Exposure to Butyrate for 3 Days}

When non-confluent MG-63 cells $\left(1 \times 10^{4}\right.$ cells/well) were cultured for 3 days, cells grew to confluence. MG-63 cells were fibroblast-like in appearance (Figure 2A). When exposed to butyrate ( $4 \mathrm{mM}$ and $8 \mathrm{mM}$ ) for 3 days, cell density of MG-63 cells decreased (Figure 2B, 2C). Exposure to $16 \mathrm{mM}$ for 3 days further decreased the cell density with space between cells. Cell became bigger and flattened in appearance (Figure 2D).

\subsection{Effect of Butyrate on the Growth and Cytotoxicity of MG-63 Cells}

Accordingly, when non-confluent MG-63 cells $\left(1 \times 10^{4}\right.$ cells/well) were exposed to butyrate (16 and $24 \mathrm{mM}$ ) for 3 days, viable cell number decreased (Figure 3A). On the other hand, when confluent MG-63 cells $\left(1 \times 10^{5}\right.$ cells/well) were exposed to butyrate for 3 days, viable cell number showed no marked difference (Figure 3B).

\subsection{Effect of Butyrate on Apoptosis and Necrosis of MG-63 Cells}

$\mathrm{PI}$ and Annexin V flow cytometric analysis was used to determine the induction of apoptosis and necrosis of MG-63 cells after exposure to various concentrations of 
butyrate. As shown in Figure 4A, exposure to $16 \mathrm{mM}$ butyrate could not evidently induce the apoptosis (UR \& LR) and necrosis (UL) of MG-63 cells. Quantitatively, the percentage of cells (\%) residing in the UL (necrotic cells) increased from $4.19 \%$ to $4.79 \%$ after exposure to $24 \mathrm{mM}$ butyrate. In addition, the percentage of cells in UR (apoptotic cells), and LR (pro-apoptotic cells) quadrant changed from $0.85 \%$ and $0.41 \%$ in control to $1.28 \%$ and $1.05 \%$ respectively by $16 \mathrm{mM}$ butyrate (Figure 4B, Table 1).

\subsection{Effect of Butyrate on OPG and RANKL mRNA and Protein Expression}

Butyrate stimulated RANKL mRNA expression ( $>1 \mathrm{mM})$, whereas it inhibited OPG mRNA expression as analyzed by RT-PCR (Figure 5A), and thus decreased the ratio of OPG/RANKL. Butyrate also stimulated RANKL protein expression (> $4 \mathrm{mM}$ ). On the contrary it inhibited OPG protein expression (> $1 \mathrm{mM}$ ) as analyzed by western blotting (Figure 5B).

\subsection{Effect of Butyrate on OPG and RANKL Secretion of MG-63 Cells}

Since OPG and RANKL secretion is important for bone turnover, we further determined their secretion MG-63 cells. Interestingly butyrate markedly inhibited the secretion of OPG in MG-63 cells at concentrations ranging 2-16 mM (Figure 5C). Unexpectedly sRANKL level in the culture medium was below detection limit (data not shown).

2.7. Effect of Butyrate on 8-Isoprostane, Pro-collagen I, MMP-2, Osteopontin, Osteonectin, and Osteocalcin Secretion of MG-63 Cells

Exposure to butyrate stimulated 8-isoprostane production of MG63 cells (Figure 6A). For matrix turnover, butyrate showed no marked effect on pro-collagen 1a1 secretion after 24 hours of exposure (Figure 6B). On the other hand, butyrate (> 1 
$\mathrm{mM}$ ) induced MMP-2 secretion of MG-63 cells (Figure $6 \mathrm{C}$ ). For mineralization markers, butyrate slightly decreased the osteonectin (SPARC) secretion, slightly increased the osteocalcin production of MG-63 cells ( $p>0.05$ ) (Figure 6D, 6E). Moreover, butyrate stimulated osteopontin secretion of MG63 cells (Figure 6F). 


\section{Discussion}

Butyrate is a well-known histone deacetylase (HDAC) inhibitor produced by microorganisms of the oral cavity and intestinal tract. Microorganisms in the root canals and periodontal pocket may generate short chain fatty acids (SCFA) including propionic acid and butyric acid, relating to periodontal/periapical tissue toxicity $[3,14]$. The levels of SCFA may reach $0.2-16 \mathrm{mM}$ in gingival crevicular fluid, and periodontal treatment may decrease the concentrations of SCFA in GCF $[9,10,14]$. In addition to P. gingivalis, other root canal microorganisms such as Fusobacterium, Actinobacteria phylum, Parvimonas micra may also generate SCFA and treatment may decrease SCFA levels [11]. They may also release various toxic factors (fimbria, endotoxin, short chain fatty acids etc.) to induce inflammatory response, and affect the viability and biological activities of periodontal and periapical tissues, leading to bony destruction. In this study, butyrate inhibited the proliferation, but showed little cytotoxic effect to MG-63 cells. Accordingly, butyrate induces minimal apoptotic and necrotic effect on MG-63 cells as analyzed by PI and annexin $\vee$ flow cytometry. Other studies have reported the apoptotic effect of butyrate on colon cancer cells, B cells and cells $[1,24,25]$. Similarly butyrate suppressed the adhesion, growth and protein synthesis of gingival epithelial cells and fibroblasts. It also induced the death and cytokine release of inflammatory cells $[9,12,14,22]$. Ho \& Chang (2007) also found the toxicity of butyrate to dental pulp cells and its relation to glutathione (GSH) depletion [26]. Interestingly proliferating MG-63 cells became bigger and flattened in appearance after exposure to butyrate. While mesenchymal stem cells are found to become flatten and spread to differentiate into osteoblasts [27], and butyrate is shown to affect differentiation of colon cancer cells and osteoblastic cells $[1,24,28,29]$. Butyrate $(0.1 \mathrm{mM})$ stimulates the expression of mineralization markers in periodontal ligament cells, whereas butyrate exhibits cytotoxicity at 
concentrations higher than $1 \mathrm{mM}$ [30]. The actual reasons and meanings for different results by butyrate are unclear and await further investigation.

SCFA have inflammatory and anti-inflammatory effects depending on cells and conditions [31,32]. As a HDAC inhibitor, butyrate may stimulate histone acetylation [1]. Interestingly, butyrate is shown to attenuate the TNF- $\alpha$ and LPS-induced IL-6, but not IL-8 of endothelial cells, via GPR41/GPR43 receptors. Butyrate prevents the TNF- $\alpha$ and LPS-induced IL-8 expression is related to inhibition of histone deacetylase (HDAC) [33]. Butyrate stimulates differentiation of mesenchymal stem cells to smooth muscle cells or osteoblasts by enhance histone $\mathrm{H} 3$ and $\mathrm{H} 4$ acetylation, down-regulation of HDAC2 or MEK/ERK-Runx2 signaling $[34,35]$. In this study, butyrate also induced the histone $\mathrm{H} 3$ acetylation of MG-63 osteoblasts. Recently stimulation of histone acetylation by HDAC inhibitors such as trichostatin A, butyrate, and valproic acid, has been shown to promote osteoblast maturation and bone formation [36]. During osteoblast differentiation, histone $\mathrm{H} 3$ and $\mathrm{H} 4$ are hyperacetylated. Knockdown of HDAC1 by siRNA also promote osteoblast differentiation [37]. These results suggest the possible effect of butyrate on bone turnover.

Previous study has found the stimulation of reactive oxygen species (ROS) production of MG-63 and other cells [23]. 8-Isoprostane (8-iso-prostaglandin F2 $\alpha$ ), as an oxidative stress marker and lipid peroxidation product, is generated by free-radical catalyzed peroxidation of essential fatty acid such as arachidonic acid, to stimulate redox-sensitive signaling pathways and transcriptional factors [38-40]. Isoprostanes may mediate vasoconstriction, tissue inflammation, perception of pain, vascular reperfusion, paracetamol poisoning, liver cirrhosis, atherosclerosis and cancer $[38,39,41]$. Limited information is known about the generation of isoprostanes by osteoblasts and their roles in bone turnover. In this study, 8-isoprostane as an oxidative stress marker was also found to be stimulated in 
MG-63 cells by butyrate, suggesting the induction of lipid peroxidation by butyrate. This may partly explain the elevated salivary, gingival crevicular fluid or root canal 8-isoprostane level in patients with periodontitis, pulpitis or chronic apical periodontitis [42-45], suggesting their involvement of increased oxidative stress in pulpal/periapical pain, periodontal and periapical bony destruction. It has been found that iso-PGE 2 but not iso-PGF 2 alpha had an inhibitory effect on the induction of alkaline phosphatase activity in MC3T3-E1 preosteoblasts [46]. Urinary F2-isoprostanes levels are found to show negatively correlation with bone mineral content and bone mineral density [47]. It has been found that patients with diabetes, obesity, hypercholesterolemia, smokers etc. have higher levels of urinary isoprostane [48]. Possibly, urinary isoprostane levels can be used as marker of periodontal and periapical diseases in the future. Increase of 8-isoprostane by butyrate suggests its involvement in the pathogenesis of periodontal/periapical diseases.

Bone turnover is tightly regulated by interaction of osteoblasts and osteoclasts [15], possibly via OPG/RANKL system. It has been shown that periodontal/root canal pathogens may stimulate RANKL expression of bone marrow cells $[19,20]$. Injection of anti-RANKL and osteoprotegerin fusion protein into rat gingiva may attenuate bone resorption induced by $P$. gingivalis infection [20]. P. gingivalis LPS is shown to induce RANKL and RANKL/OPG ratio in periodontal ligament fibroblasts [21]. An increased expression of RANK, RANKL and OPG during the progression of periodontitis and apical periodontitis has been reported [16]. Belibasakis et al. (2013) also found the protective role of OPG against root resorption and the increased apical RANKL/OPG ratio in bone resorption [17]. Level of RANKL is found to be increased, but OPG level is decreased in severe periodontitis [49]. Cyst and granuloma tissues from periapical lesions also show the increased expression of RANKL, and important of 
RANKL/OPG in apical bony destruction [17,50-52]. However, butyrate is shown to stimulate OPG expression in normal human osteoblasts [29]. In this study, butyrate was shown to stimulate RANKL, but decrease OPG expression and secretion of osteoblasts. This may partly explain why butyric acid may be involved in periodontal and periapical bony destruction and turnover.

Butyrate $(0.1 \mathrm{mM})$ stimulates calcium content, mineralized nodule formation and the expression of bone sialoprotein (BSP), osteopontin (OPN) and OPG, but showed little effect on proliferation, M-CSF, type I collagen expression and ALP activity of normal human osteoblasts [29]. Butyrate affects mainly pre-osteoblasts but not mature osteoblasts. It also stimulates ALP activity in MC3T3 osteoblasts [28]. Butyrate stimulates BSP expression in rat ROS17/2.8 osteoblast-like cells [1]. Bone sialoprotein (BSP) may function in the initial mineralization stage of bone, and is crucial for osteoblast differentiation, bone matrix mineralization and tumor metastasis [1]. On the contrary, butyrate $(1 \mathrm{mM})$ suppressed the expression of Runx2, Osterix, Dlx5, Msx2, osteocalcin, ALP and BSP expression as well as mineralized nodules formation in ROS17/2.8 osteoblasts [13]. Similarly butyrate (0.1-1 mM) also stimulate COX-2, collagen, OPN, EP1, and EP2 receptors' expression, and PGE2 production, but showed little effect on proliferation of ROS17/2.8 cells [53]. In this study, butyrate stimulated OPN, and MMP-2, but showed no marked effect on pro-collagen I, osteonectin (SPARC) and osteocalcin of MG63 osteoblastic cells. These results suggest that butyrate may affect matrix turnover and mineralization. The differential effects of butyrate may be related to differentiation status (pre-osteoblasts and osteoblasts), butyrate concentration, exposure time, cell density, and cell type etc.

We have previously found that propionate and butyrate may affect the activities including growth, attachment, migration, reactive oxygen species and cell cycle alteration of gingival fibroblasts and osteoblasts $[12,22,23]$. In conclusion, 
exposure of MG-63 osteoblastic cells to butyrate leads to histone H3 acetylation and 8-isoprostance production. Butyrate inhibited the proliferation, but not cytotoxicity and apoptosis of MG-63 osteoblasts. It further stimulates MMP-2, OPN, RANKL, but inhibit OPG expression and secretion, affecting matrix turnover and mineralization of bone tissues. These results may facilitate our understanding the role of butyric acid in the pathogenesis of apical and periodontal bony destruction, and can be helpful for disease prevention and treatment in the future. 


\section{Materials and methods}

\subsection{Materials}

Dulbecco's modified Eagle's medium (DMEM), fetal bovine serum (FBS), trypsin/EDTA, penicillin/streptomycin were from Gibco (Life Technologies, Grand Island, NY, USA). Antibodies of glyceroaldehyde-3-dehydrogenase (GAPDH) were purchased from Santa Cruz, whereas antibodies for Ac-H3, OPG and RANKL were from GeneTex. Ethidium bromide, agarose and kits for reverse transcription (RT) and polymerase chain reaction (PCR) are purchased from HT Inc., UK. Total RNA isolation kits are from Qiagen Inc. (Santa Clarita, CA, USA). Specific PCR primer sets will be synthesized by Genemed Biotechnologies, Inc. (San Francisco, CA, USA). Protein assay kits were obtained from Bio-Rad (Bio-Rad Labs, Hercules, CA, USA). Sodium butyrate was obtained from sigma (Sigma-Aldrich Company, St. Louis, MO, USA). MG-63 cells were obtained from American Type Culture Collection (ATCC). OPG, RANKL, pro-collagen I, MMP-2, osteopontin, osteocalcin and osteonectin (SPARC) ELISA kits were from R\&D. 8-Isoprostane ELISA kits were from Cayman.

\subsection{Immunofluorescent Staining of Ac-H3 Expression}

MG-63 cells $\left(1 \times 10^{5}\right)$ were seeded onto 24 -well culture with sterile coverslips in $1 \mathrm{ml}$ DMEM with 10\% FBS. After $24 \mathrm{hr}$, culture medium containing various concentrations of butyrate (1-16 mM) was added and cells were further incubated for $24 \mathrm{~h}$. MG-63 cells were also exposed to $8 \mathrm{mM}$ butyrate for different time points (5-120 min). Medium was removed, and cells were washed with PBS and fixed in $4 \%$ paraformaldehyde for 20 min. Cells were further washed with PBS, permeabilized with $2 \%$ Triton $\mathrm{X}-100$, exposed to $0.3 \% \mathrm{v} / \mathrm{v} \mathrm{H}_{2} \mathrm{O}_{2}$ for 20 minutes. After rinse with PBS, $5 \%$ bovine serum albumin (BSA) was used for blocking cells for $1 \mathrm{~h}$ and then cells were incubated with primary antibodies (Acetyl-Histone H3) $(1: 1000, v / v)$ at room 
temperature for overnight. Following washed by PBS, cells were incubated in TRITC-conjugated secondary antibodies in the dark for $1 \mathrm{~h}$ and counterstained the nucleus with DAPI (1:1000) for 30 min. Finally the cells in coverslips were mounted and photographed/observed under an inverted microscope and DP Controller/Manager software (Olympus IX71, Olympus Corporation) [23,54].

\subsection{Effect of Butyrate on Proliferation and Viability of MG-63 Cells}

Briefly $1 \times 10^{4}$ and $1 \times 10^{5} \mathrm{MG}-63$ cells/24-wells were exposed to fresh medium containing various concentrations butyrate $(2,4,8,16$ and $24 \mathrm{mM})$ for 24 hours or 3 days. Morphology of cells was taken under microscope. Viable cell number of MG-63 cells was estimated by MTT assay [22,23]. Briefly, culture medium was collected and then fresh medium containing MTT $(0.5 \mathrm{mg} / \mathrm{ml})$ was added to the attached MG-63 cells. After 2-hours of incubation, medium with MTT are removed, and DMSO was added to the wells to dissolve formazan. The viability of the cells in each well was measured by determination of optical density at $540 \mathrm{~nm}$ by a Microplate Reader.

4.4. Induce the Apoptosis and Necrosis of MG-63 Cells by PI and Annexin V Flow Cytometric Analysis

For annexin V/PI dual staining flow cytometry [55,56], $5 \times 10^{5} \mathrm{MG}-63$ cells/6-wells were exposed to $2 \mathrm{ml}$ fresh medium containing different concentrations of butyrate $(2,4,8,16$ and $24 \mathrm{mM})$ for 24 hours. Cells were collected and re-suspended in 400 $\mu \mathrm{l}, 10 \mathrm{mM}$ HEPES solution ( $\mathrm{pH} 7.4$ ) containing $140 \mathrm{mM} \mathrm{NaCl}$ and $2.5 \mathrm{mM} \mathrm{CaCl}$. Then $10 \mu \mathrm{l}$ of PI $(50 \mu \mathrm{g} / \mathrm{ml})$ and $5 \mu \mathrm{l}$ of Annexin V-FITC were added into cells for further incubation in the dark for $30 \mathrm{~min}$. After washing, the stained cells were subjected immediately to FACS Calibur Flow Cytometry (Becton Dickinson, USA) analysis of annexin V-FITC and PI fluorescence. The fluorescence of cells of samples was gated and counted. The percentage of cells localization in the upper right (apoptotic), 
upper left (necrotic cells), lower right (pro-apoptotic cells), and lower left (control) portion of the histogram was determined for comparison.

\subsection{Effect of Butyrate on the Expression of OPG, RANKL of Cultured MG-63 Cells} About $1 \times 10^{6}$ MG-63 cells in 10-cm culture dishes were exposed in fresh medium containing butyrate $(1,2,4,8,16 \mathrm{mM})$. Total RNA was isolated using Qiagen RNA isolation kits. Semi-quantitative Reverse-transcriptase and Polymerase Chain Reaction (RT-PCR)- In brief, $3 \mu \mathrm{g}$ of denatured total RNA was reverse transcripted in a total volume of $44.5 \mu \mathrm{l}$ reaction mixture containing $4 \mu \mathrm{l}$ of random primer (500 $\mu \mathrm{g} / \mathrm{ml}$ ), $8 \mu \mathrm{l}$ of dNTP (2.5 mM), $4.5 \mu \mathrm{l}$ of 10x RT buffer, $1 \mu \mathrm{l}$ of RNase inhibitor (40 $\mathrm{U} / \mu \mathrm{l})$ and $0.5 \mu \mathrm{l}$ of RT $(21 \mathrm{U} / \mu \mathrm{l})$ at $42^{\circ} \mathrm{C}$ for 90 minutes. Four microliters of cDNA were then used for PCR amplification in a reaction volume of $50 \mu \mathrm{l}$ containing $5 \mu \mathrm{l}$ of 10x Super TAQ buffer, $4 \mu \mathrm{l}$ of dNTP (2.5 mM), $1 \mu$ of each specific primer, and $0.2 \mu \mathrm{l}$ of Super TAQ enzyme $(2 \mathrm{U} / \mu \mathrm{l})$. The reaction mixture was initially heated to $94^{\circ} \mathrm{C}$ for 5 minutes in the first cycle, then the reaction was amplified for $15-35$ cycles of $94^{\circ} \mathrm{C}$ for $30 \mathrm{sec}, 55^{\circ} \mathrm{C}$ for $30 \mathrm{sec}$ and then $72^{\circ} \mathrm{C}$ for $30 \mathrm{sec}$ with a thermal cycler (Perkin Elmer 4800, PE Applied Biosystems, Foster city, CA, USA). Finally, the reaction was set at $72^{\circ} \mathrm{C}$ for further 10 minutes.

Specific primer sets for OPG: TCAAGCAGGAGTGCAATCG and AGAATGCCTCCTCACACAGG (342 bp); RANKL: CCAGCATCAAAATCCCAAGT and CCCCTTCAGATGATCCTTC (603 bp) [57]. Expression of beta-actin was used as control [58]. The amplified DNA products are loaded onto a $1.8 \%$ of agarose gel in 1X of TBE buffer for electrophoresis. Gels are stained with ethidium bromide and photographs are taken. The range of amplified DNA product that is linear in relation to the input RNA will be used for data presentation. Amplification of the BAC gene is used for a control. 
4.6. Effects of Butyrate on the OPG, RANKL and Ac-H3 Expression of MG-63 Cells MG-63 cells ( $1 \times 10^{6}$ cells) in $10 \mathrm{~cm}$ culture dishes were exposed to fresh medium containing various concentrations of butyrate $(1,2,4,8,16 \mathrm{mM})$ for $24 \mathrm{hrs}$. Cell lysates were collected as described previously using freshly prepared lysis buffer (10 mM Tris- $\mathrm{HCl}, \mathrm{pH}$ 7; $140 \mathrm{mM}$ sodium chloride; $3 \mathrm{mM}$ magnesium chloride; $0.5 \% \mathrm{NP}-40 ; 2 \mathrm{mM}$ phenylmethylsulfonyl fluoride; 1\% aprotinin; and $5 \mathrm{mM}$ dithiothreitol) [12,58-60]. The protein concentration of the cell lysates are measured by Bio-Rad protein assay kits. Equal amounts of protein (50 $\mu \mathrm{g} / \mathrm{lane})$ were separated by $12 \%$ SDS-polyacrylamide gel electrophoresis (Scie-Plas, UK) and transferred to PVDF membrane by electroblotting. The membrane was blocked for $30 \mathrm{~min}$ at room temperature in a blocking reagent (20 mM Tris, pH 7.4; $125 \mathrm{mM} \mathrm{NaCl} ; 0.2 \%$ Tween 20; 5\% nonfat dry milk; and $0.1 \%$ sodium azide) and then incubated for $2 \mathrm{hr}$ with anti-human OPG, RANKL, Ac-H3 (1:500) and GAPDH antibodies. Membranes were washed three times with TBST (10 mM Tris, pH 7.5; $100 \mathrm{mM} \mathrm{NaCl}, 0.1 \%$ Tween-20) for $10 \mathrm{~min}$ each, and then incubated with HRP-labeled goat anti-mouse secondary antibody for $1 \mathrm{hr}$. The membrane was then washed 4 times with TBST. Finally the immunoreactive bands were developed by Enhanced Chemiluminescence (ECL) reagent and visualized on Fuji X-ray film.

4.7. Effect of Butyrate on OPG, RANKL, 8-Isoprostane, Pro-collagen I, MMP-2, Osteopontin, Osteonectin and Osteocalcin Secretion of MG-63 Cells

Cells were treated by butyrate as above (Section 1.2). Culture medium was collected before MTT assay and used for enzyme-linked immunosorbant assay (ELISA) of OPG, RANKL, procollagen I, MMP-2, osteopontin, osteonectin, osteocalcin and 8-isoprostane levels according to the instruction of ELISA kit. 


\subsection{Statistical Analysis}

Three or more independent experiments were performed. The results were statistically analyzed by paired Students $t$-test. A p value $<0.05$ was regarded to have a statistically significant difference between groups.

\section{Acknowledgements}

Funding: This study is supported by Ministry of Science and Technology, Taiwan (NSC102-2314-B-255-003-MY2， NSC102-2628-B-255-001-MY3， NSC101-2320-B-255-002, NSC-100-2314-B-002-094, NSC-101-2320- B-255-002, MOST104-2314-B-255-010-MY3, MOST106-2314-B-002-034-MY2, and MOST106- 2314-B-002-033-MY2), Chang Gung Memorial Hospital (CMRPF1H0061, CMRPF1F0071, CMRPF1G0101, CMRPF1G0102, CMRPF3E0021, CMRPF3E0022, CMRPF3E0023, NMRPF3C0091, NMRPF3C0061, CMRPG1B0031, CMRPF170053, NMRPF370033, CMRPF3E0021, NMRPF3B0071, NMRPF3E0041, NMRPF3E0042, NMRPF3E0043, NMRPF3C0093, NMRPF3H0071, NMRPF3H0061, CMRPF1C0011, 1C0012) and National Taiwan University Hospital (NTUH 101-001937, NTUH102-002259, NTUH101-S1862 \& NTUH102-S2180, NTUH103-S2368, NTUH104-S2658, NTUH106-S3467, NTUH106-UN-001).

Conflict of Interest: The authors declare no conflict of interest for this submission. 


\section{References}

1. Yang, L.; Li, Z.; Li, X.; Wang, Z.; Wang, S.; Sasaki, Y.; Takai, H.; Ogata, Y. Butyric acid stimulates bone sialoprotein gene transcription. J. Oral Sci. 2010, 52, 231-237.

2. Tanner, A.; Maiden, M.F.; Macuch, P.J.; Murray, L.L.; Kent, R.L. Jr. Microbiota of health, gingivitis and initial periodontitis. J. Clin. Periodontol. 1998, 25, 85-98.

3. Nishihara, T.; Koseki, T. Microbial etiology of periodontitis. Periodontol 2000 2004, 36, 14-26.

4. Lamont, R.J.; Jenkinson, H.F. Life below the gum line: pathogenic mechanisms of Porphyromonas gingivalis. Microbiol. Mol. Biol. Rev. 1998, 62, 1244-1263.

5. Holt, S.C.; Kesavalu, L.; Walker, S.; Genco, C.A. Virulence factors of Porphyromonas gingivalis. Periodontol 2000 1999, 20, 168-238.

6. Isogai, H.; Isogai, E.; Yoshimura, F.; Suzuki, T.; Kagota, W.; Takano, K. Specific inhibition of adherence of an oral strain of Bacteroides gingivalis 381 to epithelial cells by monoclonal antibodies against the bacterial fimbriae. Arch. Oral Biol. 1988, 33, 479-485.

7. Njoroge, T.; Genco, R.J.; Sojar, H.T.; Hamada, N.; Genco, C.A. A role for fimbriae in Porphyromonas gingivalis invasion of oral epithelial cells. Infect. Immun. 1997, 65, 1980-1984.

8. Wilson, M.; Reddi, K.; Henderson, B. Cytokine-inducing components of periodontopathogenic bacteria. J. Periodont. Res. 1996, 31, 393-407.

9. Pollanen, M.T.; Overman, D.O.; Salonen, J.I. Bacterial metabolites sodium butyrate and proprionate inhibit epithelial cell growth in vitro. J. Periodont. Res. 1997, 32, 326-334.

10. Niederman, R.; Buyle-Bodin, Y.; Lu, B.Y.; Robinson, P.; Naleway, C. Short-chain carboxylic acid concentration in human gingival crevicular fluid. J. Dent. Res. 1997a, 76, 575-579. 
11. Provenzano, J.C.; Rocas, I.N.; Tavares, L.F.; Neves, B.C.; Sigueura, J.F. Short-chain fatty acids in infected root canals of teeth with apical periodontitis before and after treatment. J. Endod. 2015, 41, 831-835.

12. Chang, M.C.; Tsai, Y.L.; Chen, Y.W.; Chan, C.P.; Huang, C.F.; Lan, W.C.; Lin, C.C.; Lan, W.H.; Jeng, J.H. Butyrate induces reactive oxygen species production and affects cell cycle progression in human gingival fibroblasts. J. Periodont. Res. 2013, 48, 66-73.

13. Morozumi, A. High concentration of sodium butyrate suppresses osteoblastic differentiation and mineralized nodule formation in ROS17/2.8 cells. J. Oral Sci. 2011, 53, 509-516.

14. Niederman, R.; Zhang, J.; Kashket, S. Short-chain carboxylic-acid-stimulated, PMN-mediated gingival inflammation. Crit. Rev. Oral Biol. Med. 1997b, 8, 269-290.

15. Chen, X.; Wang, Z.; Duan, N.; Zhu, G.; Schwarz, E.M.; Xie, C. Osteoblast-osteoclast interactions. Connect. Tissue Res. 2018, 59, 99-107.

16. Barreiros, D.; Pucinelli, C.M.; Oliveira, K.M.H.; Paula-Silva, F.W.G.; Nelson Filho, P.; Silva, L.A.B.D.; Kuchler, E.C.; Silva, B.A.B.D. Immunohistochemical and mRNA expression of RANK, RANKL, OPG, TLR2 and MyD88 during apical periodontitis progression in mice. J. Appl. Oral Sci. 2018, 26, e20170512.

17. Belibasakis, G.N.; Rechenberg, D.K.; Zehnder, M. The receptor activator of NF-kB ligand-osteoprotegerin system in pulpal and periapical disease. Int. Endod. J. 2013, 46, 99-111.

18. Belibasakis, G.N.; Bostanci, N. The RANKL-OPG system in clinical periodontology. J. Clin. Periodontol. 2012, 39, 239-248.

19. Reddi, D.; Brown, S.J.; Belibasakis, G.N. Porphyromonas gingivalis induces RANKL in bone marrow stromal cells: involvement of the p38 MAPK. Microb. Pathog. 2011, 51, 415-420. 
20. Han, X.; Lin, X.; Yu, X.; Lin, J.; Kawai, T.; LaRosa, K.B.; Taubman, M.A. Porphyromonas gingivalis infection-associated periodontal bone resorption is dependent on receptor activator of NF-kB ligand. Infect. Immun. 2013, 81, 1502-1509.

21. Jung, I.H.; Lee, D.E.; Yun, J.H.; Cho, A.R.; Kim, C.S.; You, Y.J.; Kim, S.J.; Choi, S.H. Anti-inflammatory effect of (-)-epigallocatechin-3-gallate on Porphyromonas gingivalis lipopolysaccharide- stimulated fibroblasts and stem cells derived from human periodontal ligament. J. Periodont. Implant Sci. 2012, 42, 185-195.

22. Jeng, J.H.; Chan, C.P.; Ho, Y.S.; Lan, W.H.; Hsieh, C.C.; Chang, M.C. Effects of butyrate and proprionate on the adhesion, growth, cell cycle kinetics and protein synthesis of cultured human gingival fibroblast. J. Periodontol. 1999, 70, $1435-1442$.

23. Chang, M.C.; Tsai, Y.L.; Liou, E.J.; Tang, C.M.; Wang, T.M.; Liu, H.C.; Liao, M.W.; Yeung, S.Y.; Chan, C.P.; Jeng, J.H. Effect of butyrate on collagen expression, cell viability, cell cycle progression and related proteins expression of MG-63 osteoblastic cells. PLOS ONE 2016, 11, e0165438.

24. Zhang, S.; Bai, J.; Ren, S.; Wang, R.; Zhang, L.; Zuo, Y. Sodium butyrate restores ASC expression and induces apoptosis in LS174T cells. Int. J. Mol. Med. 2012, 30, 1431-1437.

25. Tailor, D.; Hahm, E.R.; Kale, R.K.; Singh, S.V.; Singh, R.P. Sodium butyrate induces DRP1-mediated mitochondrial fusion and apoptosis in human colorectal cancer cells. Mitochondrion 2014, 16, 55-64.

26. Ho, Y.C.; Chang, Y.C. Effects of a bacterial lipid byproduct on human pulp fibroblasts in vitro. J. Endod. 2007, 33, 437-441.

27. McBeath, R.; Pirone, D.M.; Nelson, C.M.; Bhadriraju, K.; Chen, C.S. Cell shape, cytoskeletal tension and RhoA regulate stem cell lineage commitment. Dev. Cell 2004, 6, 483-495. 
28. Iwami, K.; Moriyama, T. Effects of short chain fatty acid, sodium butyrate, on osteoblastic and osteoclastic cells. Int. J. Biochem. 1993, 25, 1631-1635.

29. Katono, T.; Kawato, T.; Tanabe, N.; Suzuki, N.; lida, T.; Morozumi, A.; Ochiai, K.; Maeno, M. Sodium butyrate stimulates mineralized nodule formation and osteoprotegerin expression by human osteoblasts. Arch. Oral Biol. 2008, 53, 903-909.

30. Kim, T.I.; Han, J.E.; Jung, H.M.; Oh, J.H.; Woo, K.M. Analysis of histone deacetylase inhibitor-induced response in human periodontal ligament fibroblasts. Biotechnol. Lett. 2013a, 35, 129-133.

31. Bolognini, D.; Tobin, A.B.; Milligan, G.; Moss, C.E. The pharmacology and function of receptors for short-chain fatty acids. Mol. Pharmacol. 2016, 89, 388-398.

32. Cushing, K.; Alvarado, D.M.; Ciorba, M.A. Butyrate and mucosa inflammation: New scientific evidence supports clinical observation. Clin. Transl. Gastroenterol. 2015, 6, e108.

33. Li, M.; van Esch, B.C.A.M.; Henricks, P.A.J.; Folkerts, G.; Garssen, J. The anti-inflammatory effects of short chain fatty acids on lipopolysaccharide- or tumor necrosis factor- -stimulated endothelial cells via activation of GPR41/43 and inhibition of HDACs. Front. Pharmacol. 2018, 9, 533.

34. Liu, J.; Wang, Y.; Wu, Y.; Ni, B.; Liang, Z. Sodium butyrate promotes the differentiation of rat bone marrow mesenchymal stem cells to smooth muscle cells through histone acetylation. PLOS ONE 2014, 9, e116183.

35. Chen, T.H.; Chen, W.H.; Hsu, K.H.; Kuo, C.D.; Hung, S.C. Sodium butyrate activates ERK to regulate differentiation of mesenchymal stem cells. Biochem. Biophys. Res. Commun. 2007, 355, 913-918.

36. Schroeder, T.M.; Westendorf, J.J. Histone deacetylase inhibitors promotes osteoblast maturation. J. Bone Miner. Res. 2005, 20, 2254-2263. 
37. Lee, H.W.; Suh, J.H.; Kim, A.Y.; Lee, Y.S.; Park, S.Y.; Kim, J.B. Histone deacetylase 1-mediated histone modification regulates osteoblast differentiation. Mol. Endocrinol. 2006, 20, 2432-2443.

38. Delanty, N.; Reilly, M.; Pratico, D.; FitzGerald, D.J.; Lawson, J.A.; FitzGerald, G.A. 8-Epi PGF2alpha: specific analysis of an isoeicosanoid as an index of oxidant stress in vivo. Br. J. Clin. Pharmacol. 1996, 42, 15-19.

39. Pratico, D.; Rokach, J.; Lawson, J.; FitzGerald, G.A. F2-isoprostanes as indices of lipid peroxidation in inflammatory diseases. Chem. Phys. Lipids 2004, 128, 165-171.

40. Sottero, B.; Rossin, D.; Poli, G.; Biasi, F. Lipid oxidation products in the pathogenesis of inflammation-related gut disease. Curr Med Chem 2018, 25, 1311-1326.

41. Musiek, E.S.; Morrow, J.D. F2-isoprostanes as markers of oxidant stress: an overview. Curr. Protoc. Toxicol. 2005, chapter 17, unit 17.5.

42. Huang, Y.; Zhu, M.; Li, Z.; Sa, R.; Chu, Q.; Zhang, Q.; Zhang, H.; Tang, W.; Zhang, M.; Yin, H. Mass spectrometry-based metabolomics profiling identifies alterations in salivary redox status and fatty acid metabolism in response to inflammation and oxidative stress in periodontal disease. Free. Radic. Biol. Med. 2014, 70, 223-232.

43. Vengerfeldt, V.; Mandar, R.; Saag, M.; Piir, A.; Kullisaar, T. Oxidative stress in patients with endodontic pathologies. J. Pain Res. 2017, 10, 2031-3040.

44. Khocht, A.; Rogers, T.; Janal, M.N.; Brown, M. Gingival fluid inflammatory biomarkers and hypertension in African Americans. JDR. Clin. Trans. Res. 2017, 2, 269-277.

45. Pradeep, A.R.; Rao, N.S.; Bajaj, P.; Agarwal, E. 8-Isoprostane:a lipid peroxidation product in gingival crevicular fluid in healthy, gingivitis and chronic periodontitis subjects. Arch. Oral Biol. 2013, 58, 500-504. 
46. Parhami, F.; Morrow, A.D.; Balucan, J.; Leitinger, N.; Watson, A.D.; Tintut, Y.; Berliner, J.A.; Demer, L.L. Lipid oxidation products have opposite effects on calcifying vascular cell and bone cell differentiation. A possible explanation for the paradox of arterial calcification in osteoporotic patients. Arterioscler. Thromb. Vasc. Biol. 1997, 17, 680-687.

47. Ma, E.; Ingram, K.H.; Milne, G.L.; Garvey, W.T. F2-Isoprostane reflect oxidative stress correlated with lean mass and bone density but not insulin resistance. J. Endocr. Soc. 2017, 1, 436-448.

48. Czerska, M.; Zielinski, M.; Gromadzinska, J. Isoprostanes - A novel major group of oxidative stress markers. Int. J. Occup. Med. Environ. Health 2016, 29, 179-190.

49. Liu, D.; Xu, J.K.; Figliomeni, L.; Huang, L.; Pavlos, N.J.; Rogers, M.; Tan, A.; Price, P.; Zheng, M.H. Expression of RANKL and OPG mRNA in periodontal disease: possible involvement in bone destruction. Int. J. Mol. Med. 2003, 11, 17-21.

50. Rechenberg, D.K.; Bostanci, N.; Zehnder, M.; Belibasakis, G.N. Periapical fluid RANKL and IL-8 are differentially regulated in pulpitis and apical periodontitis. Cytokine 2014, 69, 116-119.

51. Menezes, R.; Bramante, C.M.; Da Silva Paiva, K.B.; Letra, A.; Carneiro, E.; Fernando Zambuzzi, W.; Granjeiro, J.M. Receptor activator NFkappaB-ligand and osteoprotegerin protein expression in human periapical cysts and granuloma. Oral Surg. Oral Med. Oral Pathol. Oral Radiol. Endod. 2006, 102, 404-409.

52. Fan, R.; Sun, B.; Zhang, C.F.; Lu, Y.L.; Xuan, W.; Wang, Q.Q.; Yin, X.Z. Receptor activator of nuclear factor kappa B ligand and osteoprotegerin expression in chronic apical periodontitis: possible association with inflammatory cells. Chin. Med. J. 2011, 124, 2162-2166. 
53. Iida, T.; Kawato, T.; Tanaka, H.; Tanabe, N.; Nakai, K.; Zhao, N.; Suzuki, N.; Ochiai, K.; Naeno, M. Sodium butyrate induces the production of cyclooxygenases and prostaglandin E2 in ROS17/2.8 osteoblastic cells. Arch. Oral Biol. 2011, 56, 678-686.

54. Chang, M.C.; Lee, J.J.; Chen, Y.J.; Lin, S.I.; Lin, L.D.; Liou, J.W.; Huang, W.L.; Chan, C.P.; Huang, C.C.; Jeng, J.H. Lysophosphatidylcholine induces cytotoxicity/apoptosis and IL-8 production of human endothelial cells: related mechanisms. Oncotarget 2017, 8, 106177-106189.

55. Chang, M.C.; Chan, C.P.; Wang, Y.J.; Lee, P.H.; Chen, L.I.; Tsai, Y.L.; Lin, B.R.; Wang, Y.L.; Jeng, J.H. Induction of necrosis and apoptosis of KB cancer cells by sanguinarine is associated with reactive oxygen species production and mitochondrial membrane depolarization. Toxicol. Appl. Pharmacol. 2007, 218, 143-151.

56. Chang, M.C.; Chen, L.I.; Chan, C.P.; Lee, J.J.; Wang, T.M.; Yang, T.T.; Lin, P.S.; Lin, H.J.; Chang, H.H.; Jeng, J.H. The role of reactive oxygen species and hemeoxygenase-1 expression in the cytotoxicity, cell cycle alteration and apoptosis of dental pulp cells induced by BisGMA. Biomaterials 2010, 31, 8164-8171.

57. Sooampon, S.; Manokawinchoke, J.; Pavasant, P. Transient receptor potential vanilloid-1 regulates osteoprotegerin/RANKL homeostasis in human periodontal ligament cells. J. Periodont. Res. 2013, 48, 22-29.

58. Chang, M.C.; Wu, H.L.; Lee, J.J.; Lee, P.H.; Chang, H.H.; Hahn, L.J.; Lin, B.R.; Chen, Y.J.; Jeng, J.H. The induction of prostaglandin E2 production, interleukin-6 production, cell cycle arrest, and cytotoxicity in primary oral keratinocytes and KB cancer cells by areca nut ingredients is differentially regulated by MEK/ERK activation. J. Biol. Chem. 2004, 279, 50676-50683.

59. Jeng, J.H.; Ho, Y.S.; Chan, C.P.; Wang, Y.J.; Hahn, L.J.; Lei, D.; Hsu, C.C.; Chang, 
M.C. Areca nut extract up-regulates prostaglandin production, cyclooxygenase-2 mRNA and protein expression of human oral keratinocytes. Carcinogenesis 2000, 21, 1365-1370.

60. Chang, H.H.; Guo, M.K.; Kasten, F.H.; Chang, M.C.; Huang, G.F.; Wang, Y.L.; Wang, R.S.; Jeng, J.H. Stimulation of glutathione depletion, ROS production and cell cycle arrest of dental pulp cells and gingival epithelial cells by HEAM. Biomaterials 2005, 26, 745-753. 
Table 1. Induction of apoptosis and necrosis of MG63 cells by various concentrations of butyrate as analyzed by PI and Annexin V flow cytometry $(n=4)$

\begin{tabular}{|l|l|l|l|l|}
\hline & Control & $8 \mathrm{mM}$ Butyrate & $16 \mathrm{mM}$ Butyrate & $24 \mathrm{mM}$ Butyrate \\
\hline UR & $0.85 \pm 0.10$ & $1.25 \pm 0.19$ & $1.28 \pm 0.2$ & $1.43 \pm 0.40$ \\
\hline UL & $4.19 \pm 1.12$ & $4.19 \pm 0.57$ & $4.24 \pm 0.51$ & $4.79 \pm 0.33$ \\
\hline LR & $0.41 \pm 0.06$ & $0.86 \pm 0.21$ & $1.05 \pm 0.30$ & $0.75 \pm 0.24$ \\
\hline LL & $94.54 \pm 1.05$ & $93.69 \pm 0.31$ & $93.41 \pm 0.18$ & $93.02 \pm 0.36$ \\
\hline
\end{tabular}




\section{Figure Legends}

Figure 1. Stimulation of Histone H3 acetylation of MG63 cells as analyzed by IF and western blotting. (A) IF pictures of $\mathrm{Ac}-\mathrm{H} 3$ expression: control (0 min), and Butyrate (8 mM)-treated MG63 cells for 120 min. (B) IF pictures of Ac-H3 expression: Control (24 hours) and Butyrate ( 8 mM)-treated MG63 cells for 24 hours, (C) Western blotting of control and 8 mM butyrate-treated MG-63 cells for 24 hours. One representative IF study result was shown.

Figure 2. Morphologic changes of MG63 cells after exposure to butyrate for 3 days. MG63 cells ( 1 x 10000 cells/24-well) were exposed to butyrate for 3 days. (A) Control MG 63 cells, (B) Exposure to $4 \mathrm{mM}$ butyrate for 3 days, (C) Exposure to $8 \mathrm{mM}$ butyrate for 3 days, (D) Exposure to $16 \mathrm{mM}$ butyrate for 3 days. 100x original magnification. One representative result was shown.

Figure 3. Effect of butyrate on the growth and cytotoxicity of MG63 cells (A) MG63 cells (1 x 10000 cells/24-well) were exposed to butyrate for 3 days, (B) About confluent MG63 cells ( 1 x 100000 cells/24-well) were exposed to butyrate for 3 days. Cell number was estimated by MTT assay. Results were expressed as percentage of control (Mean $\pm \mathrm{SE})$. *denotes statistically significant difference when compared with control $(p<0.05)$.

Figure 4. Effect of butyrate in the induction of apoptosis and necrosis of MG63 cells as, analyzed by PI + Annexin V flow cytometry. UL: necrosis, UR and LR: apoptosis, One representative $\mathrm{PI}$ and Annexin $\mathrm{V}$ flow cytometry histogram was shown. (A) Control, and $16 \mathrm{mM}$ butyrate-treated cells, (B) quantitative analysis of cells residing in upper left, upper right, lower left and lower right region. (Mean $\pm S E)(n=4)$ 
Figure 5. Effect of butyrate on OPG and RANKL expression of MG63 osteoblastic cells. (A) RT-PCR analysis of mRNA expression, (B) Western blot analysis of OPG and RANKL protein expression, (C) ELISA analysis of OPG level in culture medium. *denotes statistically significant difference when compared with control $(p<0.05)$.

Figure 6. Effect of butyrate on 8-isoprostane, pro-collagen I, MMP-2, osteonectin (SPARC), osteocalcin, and osteopontin (OPN) secretion of MG-63 cells as analyzed by ELISA. (A) 8-Isoprostane level, (B) Pro-collagen I level, (C) MMP-2 secretion, (D) Osteonectin (SPARC) secretion, (E) osteocalcin level, (F) osteopontin (OPN) secretion. Results were expressed as Mean \pm SE. *denotes statistically significant difference when compared with control. 
Figure 1

(A) Control

$120 \min$
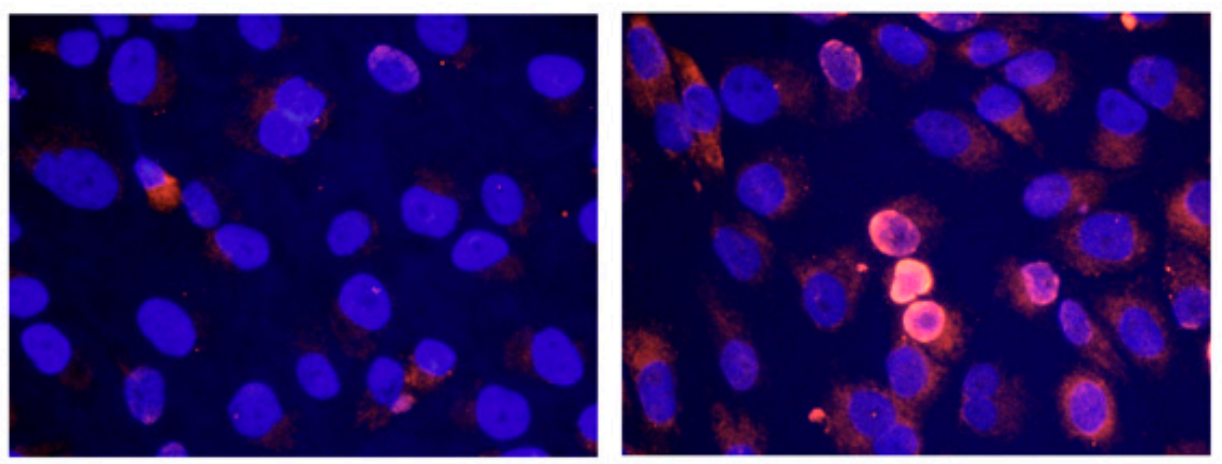

(B)

Control

$8 \mathrm{mM}$ Butyrate
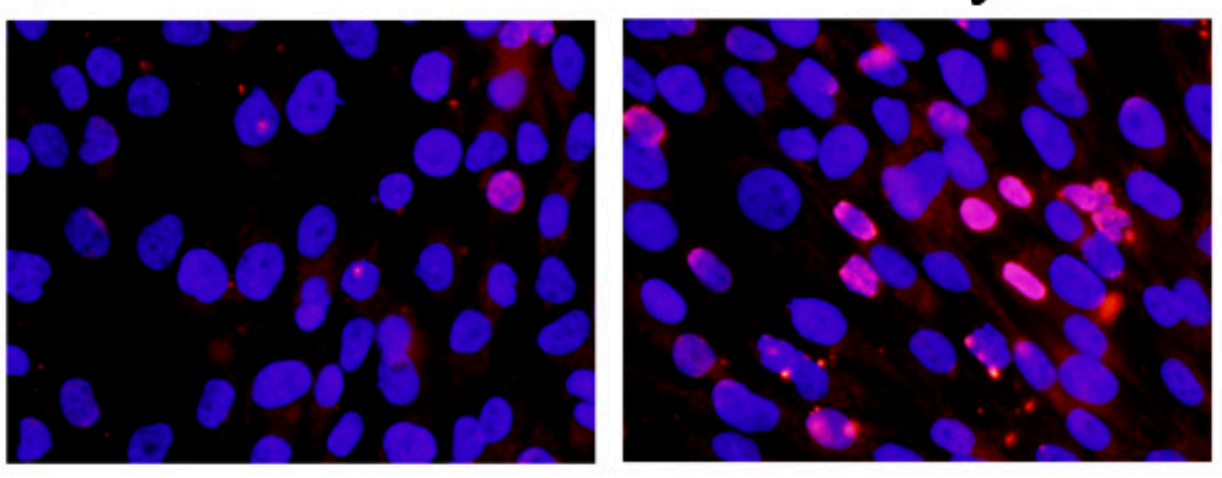

(C)

\section{$\begin{array}{llll}\text { MW } & 0 & 8 & \text { Butyrate }(\mathrm{mM})\end{array}$}

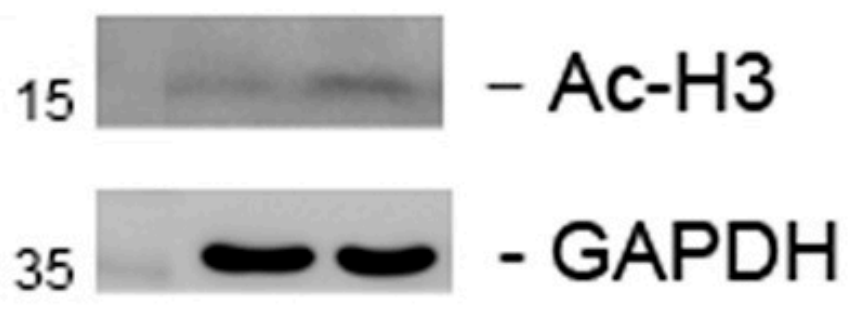




\section{Figure 2.}
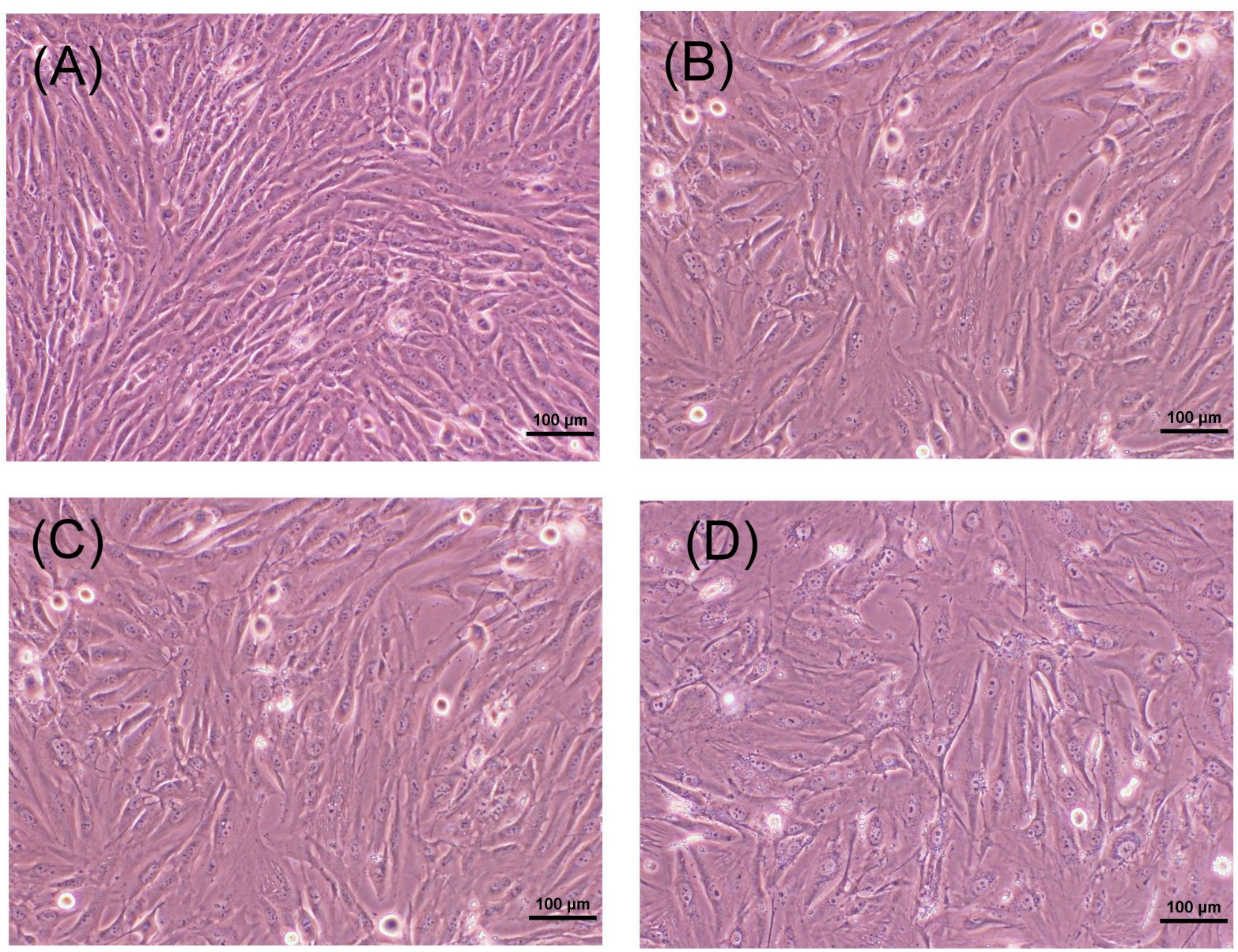
Figure 3.

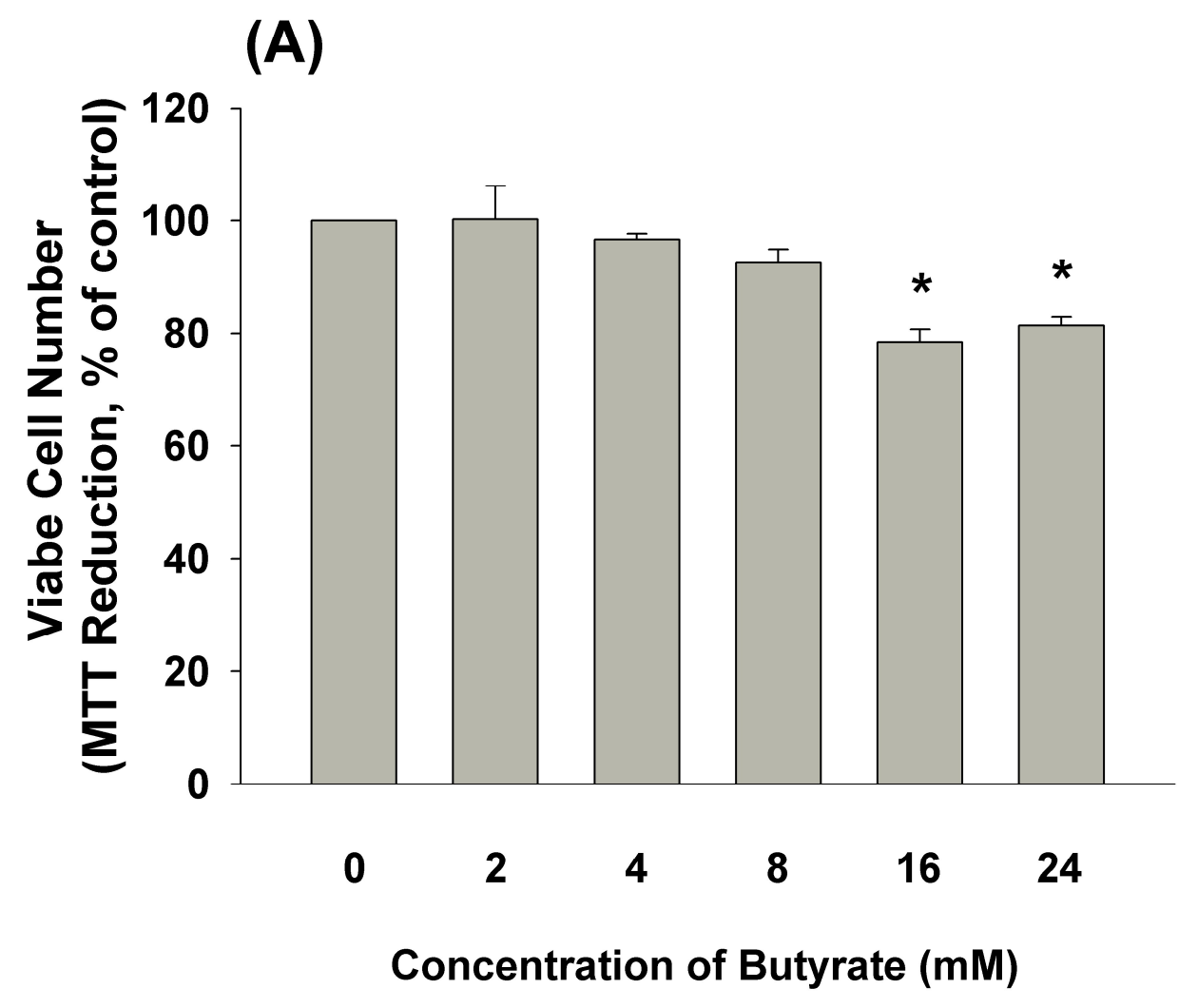

(B)

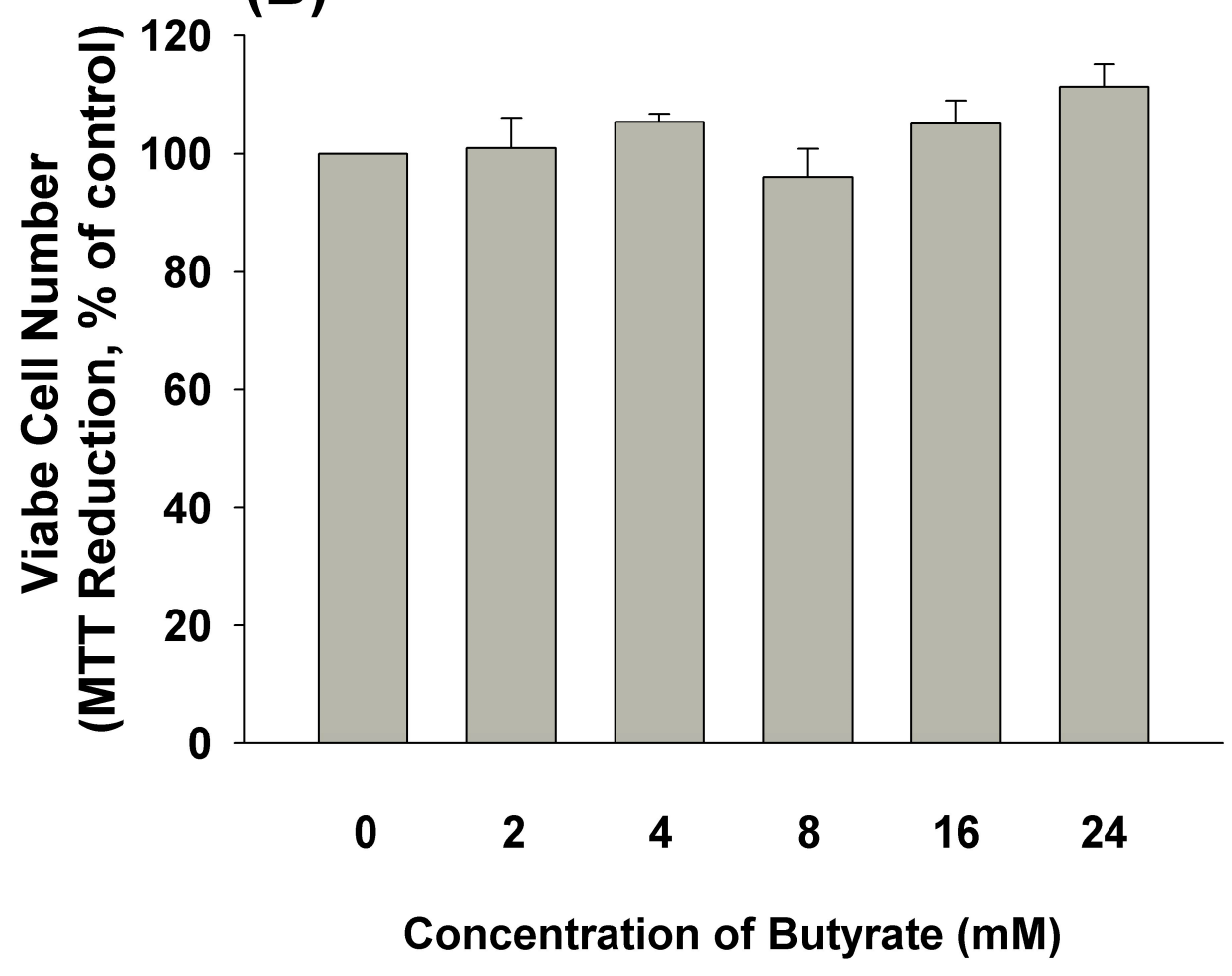




\section{Figure 4}

\section{(A) control}

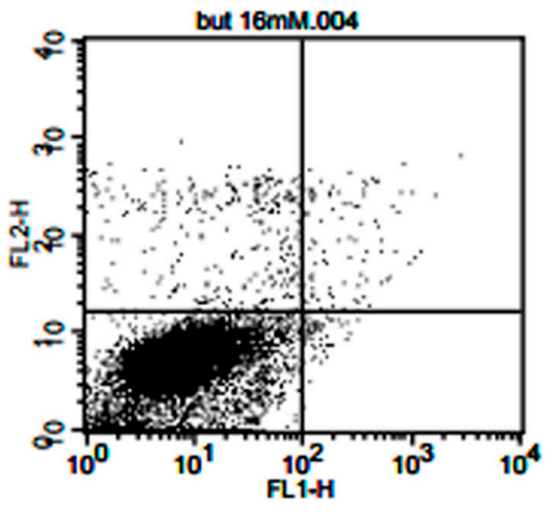

File: but $16 \mathrm{~mm} .004$

\begin{tabular}{crr} 
Quad & \% Gated & \% Total \\
\hline UL & 4.62 & 4.62 \\
UR & 0.92 & 0.92 \\
LL & 93.83 & 93.83 \\
LR & 0.63 & 0.63
\end{tabular}

\section{$16 \mathrm{mM}$ butyrate}

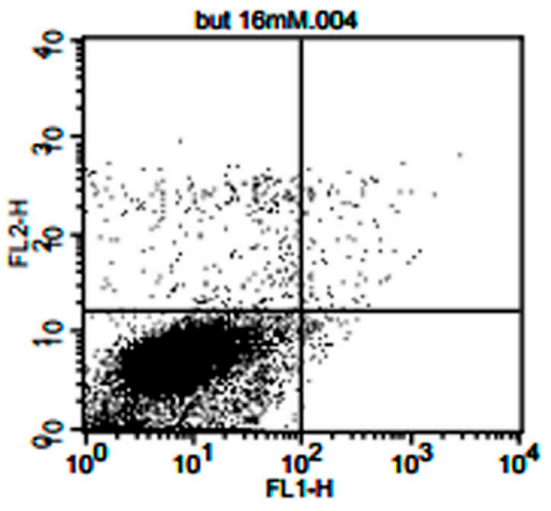

File: but $16 \mathrm{mM} .004$

\begin{tabular}{crr} 
Quad & $\%$ Gated & $\%$ Total \\
\hline UL & 4.62 & 4.62
\end{tabular}

$\begin{array}{lll}\text { UR } & 0.92 \quad 0.92\end{array}$

L $\quad 93.83 \quad 93.83$

$\begin{array}{lll}\text { LR } & 0.63 \quad 0.63\end{array}$

(B)

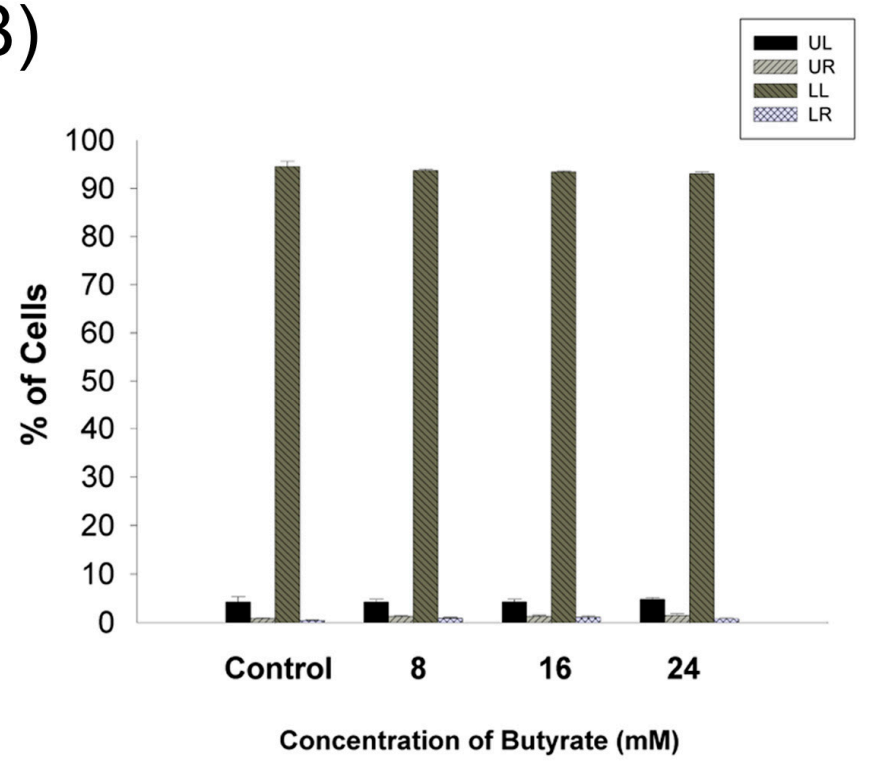




\section{Figure 5.}

(A)

\section{Butyrate Concentration}

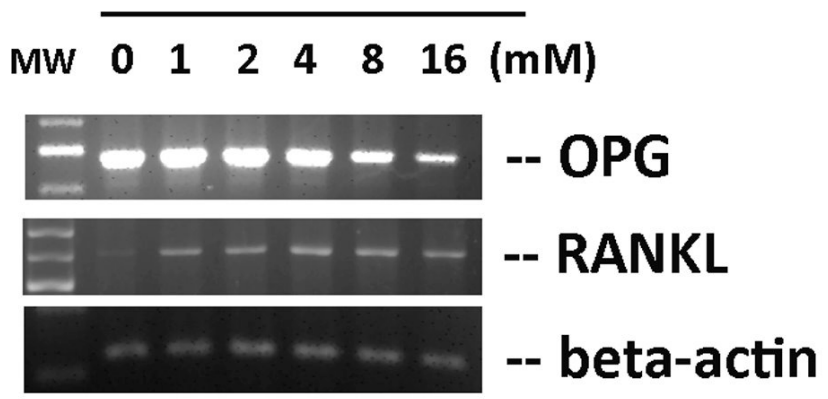

(B)

\section{Concentration of Butyrate}

$\begin{array}{lllllll}M & 0 & 1 & 2 & 4 & 8 & 16 \\ & m M\end{array}$

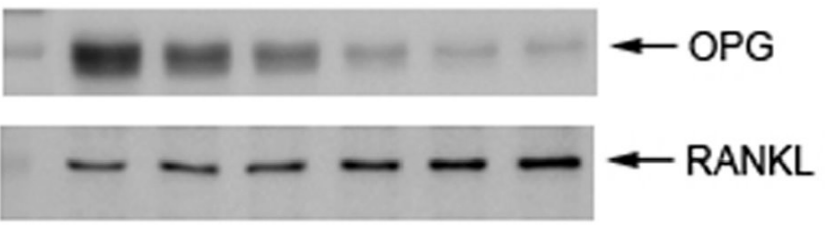

$\longrightarrow-\infty-\mathrm{GAPDH}$

(C)

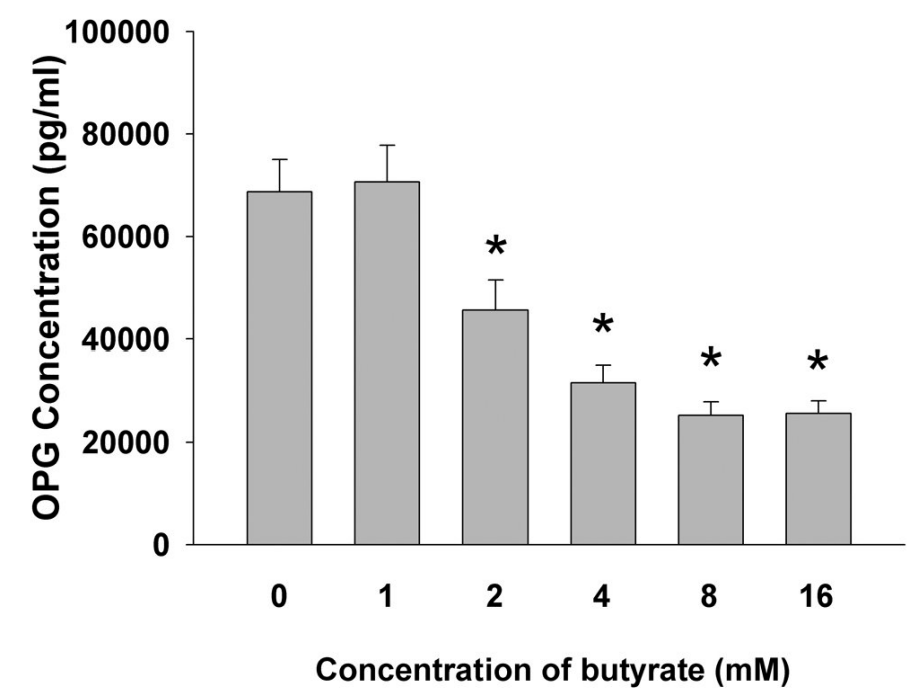




\section{Figure 6}
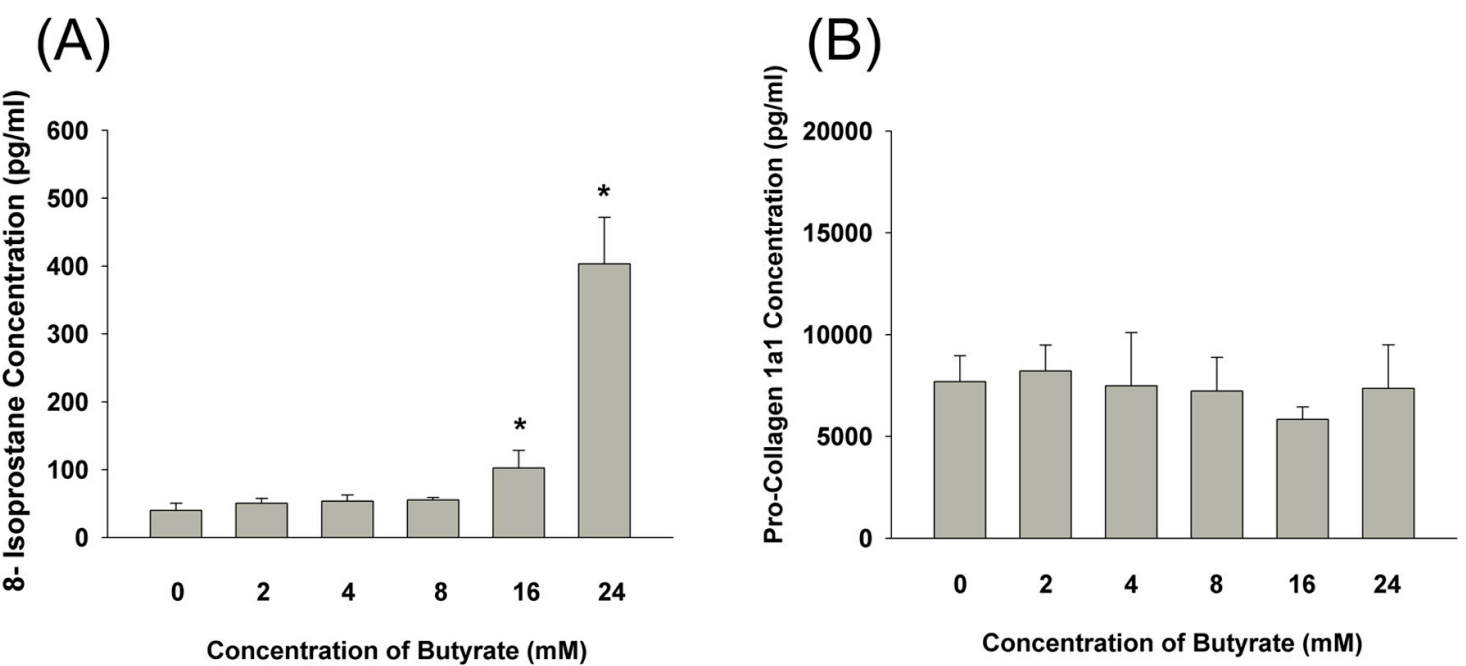

(C)
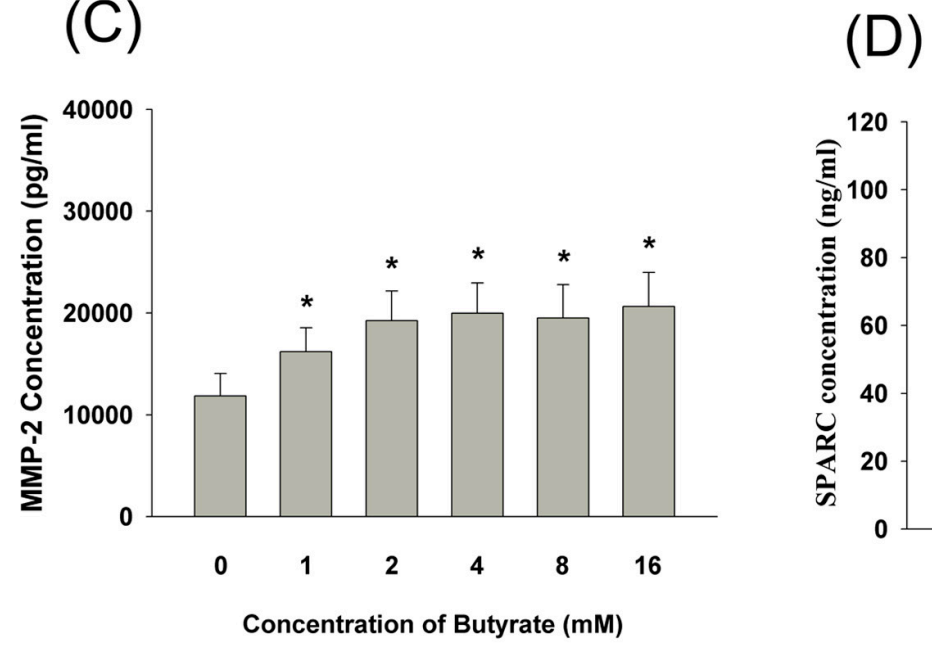

(E)

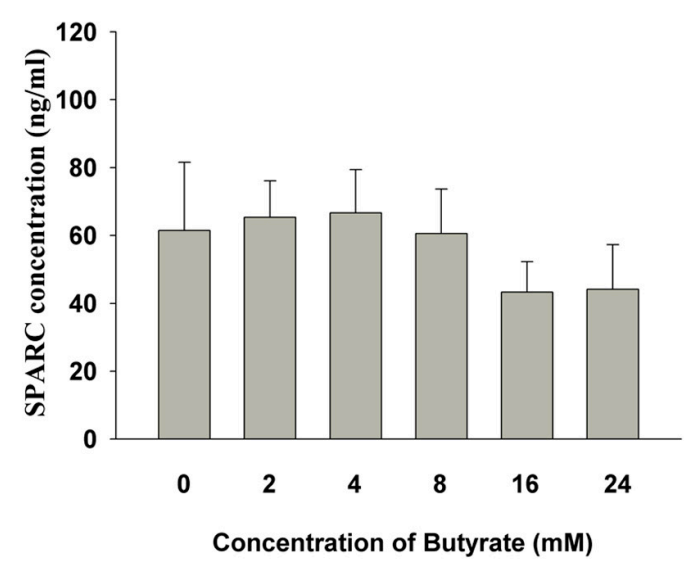

(F)
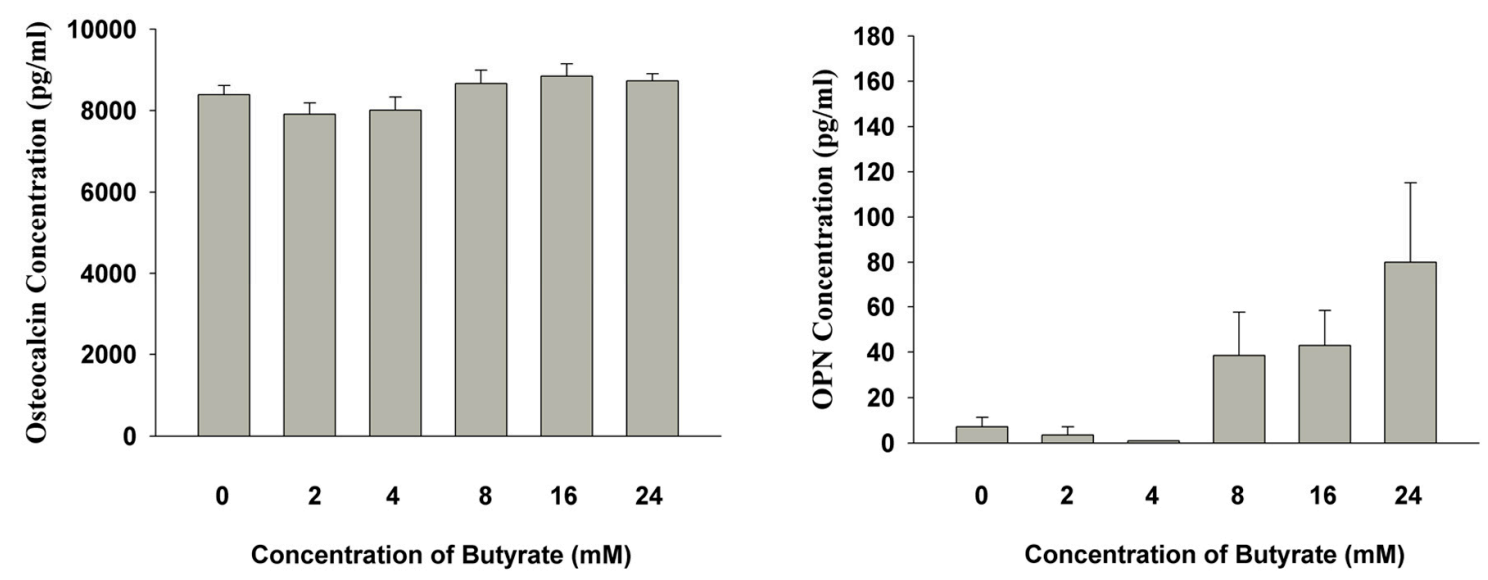